\title{
Profile of Anti-IL-5 mAb Mepolizumab in the Treatment of Severe Refractory Asthma and Hypereosinophilic Diseases [Corrigendum]
}

\author{
Menzella F, Lusuardi M, Galeone C, Taddei S, Zucchi \\ L. J Asthma Allergy. 2015;8:105-114.
}

Page 107, Table 1, Efficacy column, Asthma row, the text "Mepolizumab reduces peripheral blood eosinophilia, percentage of bone marrow eosinophils, airway eosinophils, and rate of exacerbations in almost all RCTs. Improvements in FEV 1 were found in only two studies "13,36" should read "Mepolizumab reduces peripheral blood eosinophilia, percentage of bone marrow eosinophils, airway eosinophils, and rate of exacerbations in almost all RCTs".

The authors apologize for this error.

\section{Publish your work in this journal}

The Journal of Asthma and Allergy is an international, peer-reviewed open-access journal publishing original research, reports, editorials and commentaries on the following topics: Asthma; Pulmonary physiology; Asthma related clinical health; Clinical immunology and the immunological basis of disease; Pharmacological interventions and new therapies. The manuscript management system is completely online and includes a very quick and fair peer-review system, which is all easy to use. Visit http://www.dovepress.com/testimonials.php to read real quotes from published authors. 